Journal of Management and Bussines (JOMB)

Volume 1, Nomor 2, Desember 2019

p-ISSN : 2656-8918

e-ISSN: $2684-8317$

DOI : https://doi.org/10.31539/jomb.v1i2.791

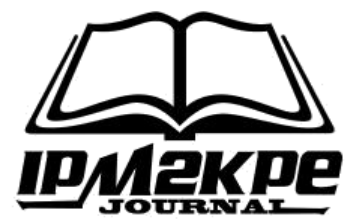

\title{
ANALISIS STRATEGI PENGEMBANGAN USAHA GUNA MENINGKATKAN MODAL KERJA DAN KEUNTUNGAN DI PERUSAHAAN ROTI TIGA BERLIAN KOTA LUBUKLINGGAU
}

\author{
Wisdalia Maya Sari d. ${ }^{1}$, Fitria $^{2}$, Prilia Dwi Hartina ${ }^{3}$ \\ Universitas Bina Insan Lubuklinggau ${ }^{1,2,3}$ \\ wisdaliams6@gmail.com ${ }^{1}$
}

\begin{abstract}
ABSTRAK
Tujuan dari penelitian ini adalah untuk mengetahui modal kerja di perusahaan yang diteliti, mengetahui keuntungan perusahaan di tempat penelitian, membuat strategi pengembangan perusahaan. Penelitian ini dilakukan di perusahaan Roti Tiga Berlian Kota Lubuklinggau. Metode yang digunakan didalam penelitian ini adalah metode deskriptif kuantitatif dengan analisis modal kerja, keuntungan dan SWOT. Hasil dari penelitian ini adalah sistem pemodalan dimanfaatkan dengan baik, pengelolaan modal kerja yang dimiliki memperoleh keuntungan, rekomendasi untuk pengembangan perusahaan, yakni: 1) menambah keberahaman varian roti; 2) membuka pabrik di wilayah yang strategis; 3) membangun otlet-otlet khusus untuk produk roti tiga berlian. Simpulan, kondisi Perusahaan Roti Tiga Berlian Kota Lubuklinggau dalam mengelola modal kerja yang dimiliki untuk memperoleh keuntungan maka dalam keadan sehat, sehingga selama 5 (lima) tahun diketahui bahwa mampu menggunaakn modal kerja yang dimiliki untuk mendapatkan laba
\end{abstract}

Kata Kunci : Strategi Pengembangan, Modal Kerja, Keuntungan

\section{ABSTRACT}

The purpose of this study is to determine the working capital in the company under study, find out the company's profits in the research site, make a company development strategy. This research was conducted at the Roti Tiga Berlian company in the City of Lubuklinggau. The method used in this research is quantitative descriptive method with working capital, profit and SWOT analysis. The results of this study are that the capital system is put to good use, working capital management has gained profits, recommendations for company development, namely: 1) increasing the understanding of bread variants; 2) opening factories in strategic areas; 3) build special otlets for three-diamond bread products. Conclusion, the condition of the Lubuklinggau City Tiga Berlian Bread Company in managing working capital owned to obtain profit is in a healthy condition, so that for 5 (five) years it is known that it is able to use the working capital owned to obtain profit

Keywords: Development Strategy, Working Capital, Profit 


\section{PENDAHULUAN}

Perkembangan dunia ekonomi dan dunia bisnis yang semakin cepat menuntut perusahaan agar dapat mengelola suatu sistem manajemen yang baik. Pengendalian manajemen merupakan proses dimana manajer mempengaruhi anggota lainnya dalam organisasi untuk menjalankan strategi organisasi (Hery, 2014). Sedangkan manajemen keuangan merupakan penggabungan dari ilmu dan seni yang membahas, mengkaji dan menganalisis tentang bagaimana seseorang manajemen keuangan dengan menggunakan seluruh sumberdaya perusahaan untuk mencari dana, mengelola dana,dan membagi dana dengan tujuan mampu memberikan profit atau kemakmuran bagi para pemegang saham dan suistainability (keberlanjutan) usaha bagi perusahaan (Fahmi, 2014)

Begitu banyaknya usaha-usaha baru yang didirikan mulai dari usaha yang kecil, menengah, maupun usaha besar sehingga dapat menimbulkan persaingan yang semakin ketat antar wirausaha.Oleh karena itu untuk mengatasi persaingan tersebut, setiap wirausaha perlu mempunyai strategi yang tepat untuk memasarkan produknya, baik itu dari strategi manajemen sumber daya manusia yang hebat dan mampu menumbuhkan kreativitas tanpa batas semua personel yang terlibat dalam pemasaran produk. Adanya persaingan antar pelaku-pelaku ekonomi yakni Badan Usaha Milik Negara, perusahaan-perusahaan swasta, dan usaha kecil menengah membuat perusahaan yang mampu bersaing akan bertahan. Sebaiknya, perusahaan yang tidak mampu bersaing kemungkinan akan dilikuidasi atau mengalami kebangkrutan.

Menurut Undang-undang No 32 Tahun 1998, bahwa usaha kecil merupakan bagian integral dari perekonomian nasional yang mempunyai kedudukan, potensidan peranan yang penting dan strategis dalam mewujudkan pembangunan ekonomi nasional yang kokoh untuk mewujudkan perekonomian nasional yang kokoh tersebut, usaha kecil perlu diberdayakan agardapat menjadi usaha kecil yang tangguh dan mandiri serta dapat berkembang menjadi usaha menengah berdasarkan pertimbangan tersebut dan sesuai dengan ketentuan Undang-undang Nomor 9 Tahun 1995tentang Usaha Kecil, dipandang perlu mengatur pembinaan dan pengembangan usaha kecil dalam Peraturan pemerintah.

Strategi seperangkat tujuan rencana tindakan yang spesifik, yang apabila dicapai akan memberikan keunggulan kompetitif, serta menjelaskan bagaimana suatu organisasi menyelaraskan kemampuannya dengan peluang yang ada dipasar untuk 
mencapai tujuan perusahaan. Dengan adanya persediaan suatu barang akan mempengaruhi peningkatan dan penurunan penjualan.Terkait dengan hal tersebut setiap badan uasaha dalam menjalankan aktivitas usaha selalu membutuhkan modal kerja. Namun kebutuhan akan modal kerja sering tidak diimbangi dengan pengelolaan yang baik dari pihak manajemen sehingga menimbulkan kukurangan bahkan kelebihan modal kerja. Modal sangat penting sebab tanpa modal suatu organisasi atau perusahaan tidak akan bisa akan bisa berjalan sebagaimana mestinya. Namun dalam perkembangannya modal usaha bisa juga berasal dari pinjaman baik dari perusahaan sendiri, di luar seperti perbankan.

Agar dapat mengetahui kemampuan suatu perusahaan roti tiga berlian dalam menghasilkan laba yang efisiensi aktivitas operasinya maka diperlukan alat analisis yang dinamakan rasio profitabilitas. Rasio ini mengukur efektivitas manajemen secara keseluruhan yang ditunjukan oleh besar kecilnya tingkat keuntungan yang diperoleh dalam hubungannya dengan penjualan maupun investasi (Fahmi, 2014). Semakin baik rasio profitabilitas maka semakin baik menggambarkan kemampuan tingginya perolehan keuntungan yang di dapat oleh perusahaan roti tiga berlian. Salah satu tujuan dari sebuah perusahaan roti tiga berlian ini adalah mendapatkan laba yang maksimal. Keuntungan atau laba merupakan sarana penting untuk mempertahankan kelangsungan hidup perusahaan, semakin tinggi laba yang diharapkan maka perusahaan akan mampu bertahan hidup, tumbuh dan berkembang serta tanguh menghadapi persaingan. Diperlukan manajeman dengan tingkat efektifitas yang tinggi untuk mencapai tujuan perusahaan tersebut, pengukuran tingkat efektifitas manajeman yang ditunjukkan oleh laba yang dihasilkan dari penjualan roti dan pendapatan infestasi, dapat dilakukan dengan mengetahui seberapa besar Rasio profitabilitas yang dimiliki. Dengan mengetahui rasio profitabilitas yang dimilki, perusahaan dapat memonitor perkembangan peruahaan dari waktu ke waktu dalam memproduksi roti untuk mencapai sebuah keuntungan yang ingin dicapai oleh perusahaan.

Modal kerja bersih atau Net Working Capital Aktiva lancar mengalami penurunan pada tahun 2015 sebesar Rp. 1.140.746.000 sedangkan hutang lancar mengalami peningkatan pada tahun 2014 sebesar Rp. 208.880.000. Return On Equity adanya peningkatan modal sendiri pada tahun 2015 sebesar Rp. 981.680 .000 , tahun 2016 sebesar 752.340.000 dan pada tahun 2017 terjadi peningkatan sebesar Rp. 
762.831.000 tetapi tidak sebanding dengan tahun 2015 yang tidak diikuti dengan penigkatan laba bersih. Dari data yang didapat Peneliti menemukan masalah, keuntungan perusahan tidak sesuai dengan modal yang dikelurkan perusahaan, dalam hal ini peneliti tertarik untuk melakukan penelitian terhadap perusahaan tersebut untuk menganalisis manajemen strategi yang ada dalam perusahaan guna meningkatkan keuntungan perusahaan.

\section{KAJIAN TEORI}

\section{Strategi}

Menurut Fahmi (2014) metode yang digunakan dalam strategi ini yaitu rasio aktivitas karena rasio yang digunakan ini untuk menggambarkan seujauh mana suatu perusahaan mempergunakan sumber daya yang dimilikinya guna menunjang aktivitas perusahaan, dimana penggunaan aktivitas ini dilakukan secara sangat maksimal dengan maksud memperoleh hasil yang maksimal.

Analisis SWOT adalah suatu bentuk analisis di dalam manajemen perusahaan atau di dalam organisasi yang secara sistematis dapat membantu dalam usaha penyusunan suatu rencana yang matang untuk mencapai tujuan, baik itu tujuan jangka pendek maupun tujuan jangka panjang.Atau definisi analisis SWOT yang lainnya yaitu sebuah bentuk analisa situasi dan juga kondisi yang bersifat deskriptif (memberi suatu gambaran).Analisa ini menempatkan situasi dan juga kondisi sebagai sebagai faktor masukan, lalu kemudian dikelompokkan menurut kontribusinya masing-masing. Satu hal yang perlu diingat baik-baik oleh para pengguna analisa ini, bahwa analisa SWOT ini semata-mata sebagai suatu sebuah analisa yang ditujukan untuk menggambarkan situasi yang sedang dihadapi, dan bukan sebuah alat analisa ajaib yang mampu memberikan jalan keluar yang bagi permasalahan yang sedang dihadapi.

SWOT adalah singkatan dari:

$\mathrm{S}=$ Strength (kekuatan).

$\mathrm{W}=$ Weaknesses (kelemahan).

$\mathrm{O}=$ Opportunities (Peluang).

$\mathrm{T}=$ Threats (hambatan) 
Penjelasan mengenai 4 (empat) komponen analisis SWOT, yaitu :

1. Strenght (S), Yaitu analisis kekuatan, situasi ataupun kondisi yang merupakan kekuatan dari suatu organisasi atau perusahaan pada saat ini. Yang perlu di lakukan di dalam analisis ini adalah setiap perusahaan atau organisasi perlu menilai kekuatan-kekuatan dan kelemahan di bandingkan dengan para pesaingnya. Misalnya jika kekuatan perusahaan tersebut unggul di dalam teknologinya, maka keunggulan itu dapat di manfaatkan untuk mengisi segmen pasar yang membutuhkan tingkat teknologi dan juga kualitas yang lebih maju.

2. Weaknesses (W)Yaitu analisi kelemahan, situasi ataupun kondisi yang merupakan kelemahan dari suatu organisasi atau perusahaan pada saat ini. Merupakan cara menganalisis kelemahan di dalam sebuah perusahaan ataupun organisasi yang menjadi kendala yang serius dalam kemajuan suatu perusahaan atau organisasi.

3. Opportunity (O)Yaitu analisis peluang, situasi atau kondisi yang merupakan peluang diluar suatu organisasi atau perusahaan dan memberikan peluang berkembang bagi organisasi dimasa depan. Cara ini adalah untuk mencari peluang ataupun terobosan yang memungkinkan suatu perusahaan ataupun organisasi bisa berkembang di masa yang akan depan atau masa yang akan datang.

4. Threats (T)Yaitu analisis ancaman, cara menganalisis tantangan atau ancaman yang harus dihadapi oleh suatu perusahaan ataupun organisasi untuk menghadapi berbagai macam faktor lingkungan yang tidak menguntungkan pada suatu perusahaan atau organisasi yang menyebabkan kemunduran. Jika tidak segera di atasi, ancaman tersebut akan menjadi penghalang bagi suatu usaha yang bersangkutan baik di masa sekarang maupun masa yang akan datang.

\section{Prinsip - Prinsip Dasar Modal Kerja}

Jumingan (2016) untuk membelanjai operasi perusahaan dari hari kehari, misalnya untuk memberi uang muka pada pembelian bahan baku atau barang dagang, membayar upah buruh dan gaji pegawai, dan biaya - biaya lainnya, setiap perusahaan perlu menyediakan modal kerja. Sejumlah dana yang telah dikeluarkan untuk membelanjai operasi perusahaan tersebut diharapkan akan dapat kembali lagi masuk dalam perusahaan dalam jangka waktu pendek melalui hasil penjualan barang dagangan atau hasil produksinya. Uamg yang masuk yang bersumber dari hasil penjualan barang 
tersebut akan dikeluarkan kembali guna membiayai operasi perusahaan selanjutnya. Dengan demikian, uang atau dana tersebut akan berputar secara terus - menerus setiap periodenya sepanjang hidupnya perusahaan.

\section{Metode Modal Kerja}

Menurut Hery (2014) Metode yang digunakan dalam modal kerja yaitu :

1. Aset Lancar Kas dan aktiva lainnya yang diharapkan akan dapat dikoversi menjadi kas, dijual atau dikonsumsi dalam satu tahun dalam satu siklus operasi tergantung mana yang paling lama (Hery, 2014). Aktiva lancar mencakup uang kas, aktiva lainnya, atau sumber lainnya yang diharapkan dapat direalisasikan menjadi uang kas, atau dijual, atau dikonsumsi selama jangka waktu normal (Jumingan, 2016). Aktiva lancar merupakan harta atau kekayaan yang segera dapat diuangkan (ditunaikan) pada saat dibutuhkan dan paling lama satu tahun (Kasmir, 2015).

2. Kewajiban Lancar. Kewajiban lancar adalah kewajiban ang diperkirakan akan dibayar dengan menggunakan aset lancar atau menciptakan kewajiban lancar lainnya dan harus segera dilunasi dalam jangka waktu satu tahun atau dalam dalam satu siklus operasi normal perusahaan, tergantung mana yang paling lama (Hery, 2014). Semua kewajiban keuangan perusahaan yang pelunasannya atau pembayaran akan dilakukan dalam jangka pendek (satu tahunsejak tanggal neraca) dengan menggunakan aktiva lancar yang dimiliki oleh perusahaan (Munawir, 2016).

3. Kewajiban perusahaan kepada pihak lain yang harus dipenuhi dalam jangka waktu yang normal (Jumingan, 2016).

Perputaran Modal kerja (Working Capital Turn Over) merupaka rasio yang digunakan untuk mengukur keefektifan modal kerja (Aset Lancar) yang dimiliki perusahaan dalam menghasilkan penjualan (Herry, 2014)

Rasio Perputaran Modal Kerja $=\quad \frac{\text { Penjualan }}{\text { Modal }}$


Table 1 Standar Industri Perhitungan Perputaran Modal Kerja

\begin{tabular}{cl}
\hline \multicolumn{1}{c}{$\begin{array}{c}\text { Standar industri } \\
\text { Keterangan } \\
\text { Sehat/ Tidak Sehat }\end{array}$} \\
\hline $80<100 \quad$ Sehat \\
$60<80$ & Cukup Sehat \\
$40<60$ & Kurang sehat \\
$20<40$ & Tidak sehat \\
$0<20$ & Sangat tidak sehat \\
Sumber: & Peraturan menteri Negara Koperasi dan UKM Repbublik Indonesia \\
Nomor 6/Per/M.KUKM/IX/2012
\end{tabular}

Berdasarkan pendapat - pendapat di atas maka dapat dikatakan metode dalam modal kerja adalahMetode ini menentukan kebutuhan modal kerja dengan memperhatikan perputaran elemen pembentuk modal kerja itu sendiri seperti kas, piutang, penjualan, persediaan dan kewajiban lancar.

\section{Prinsip - Prinsip DasarKeuntungan}

Rasio profitabilitas dapat dilakukan dengan menggunakan perbandingan antara berbagai kmponen yang ada di laporan keuangan terutama laporan dineraca maupun laba rugi, dengan memperoleh laba yang maksimal seperti yang telah ditargetkan, perusahaan dapat berbuat banyak bagi kesejahteraan pemilik, karyawan, serta meningkatkan mutu produk dan melakukan investasi baru.oleh karena itu, manajeman perusahaan dalam prktiknya dituntut harus mampu untuk memenuhi target yang telah ditetapkan (Kasmir, 2015). Suatu yang menggambarkan kemampuan perusahaan dalam menghasilkan laba melalui semua kemampuan dan sumber daya yang dimilikinya, yaitu yang berasal dari kegiatan penjualan, penggunaan aset, maupun penggunaan modalpengukuran dapat dilakukan dengan membandingkan antara berbagai komponen yang ada di dalam laporan laba rugi atau neraca (Hery, 2014).

\section{Metode Keuntungan}

Kasmir (2015) dalam menghitung rasio profitabilitas dilakukan dengan 3 analisis yaitu Return On Equity (ROE). Menurut Kasmir (Profit Margin Om Sales merupakan salah satu rasio yang digunakan untuk mengukur margin laba/ atas penjualan.

Return On Equity Merupakan rasio untuk mengukur laba bersih sesudah pajak dengan modal sendiri. Cara mengukur rasio ini dapat mengunakan rumus: 


Return On Equity $=\quad \frac{\text { Earning after Interest and Tax }}{\text { Equity }}$

Berikut adalah jenis - jenis rasio rasio profitabilitas yang digunakan dalam praktek untuk mengukur kemampuan perusahaandalam menghasilkan laba Menurut Hery (2014) yaitu Hasil Pengembalian atas Aset (Return on Assets), Hasil Pengembalian atas Ekuitas (Return on Equity), Marjin Laba Bersih (Net Profit Margin).

Tabel 2Standar Industri Return on Equity

\begin{tabular}{ll}
\hline \multicolumn{1}{c}{ Standar } \\
Kriteria & \\
\hline$>21 \%$ & Sehat \\
$15 \%-<21 \%$ & Cukup sehat \\
$9 \%-<15 \%$ & Kurang sehat \\
$3 \%-<9 \%$ & Tidak sehat \\
$<3 \%$ & Sangat tidak sehat \\
& \\
\hline
\end{tabular}

Dari penjelasan di atas maka Peneliti menyimpulkan, Metode profitabilitas adalahRasio ini mengukur laba bersih setelah pajak terhadap penjualan dan perbandingan antara laba bersih sesudah pajak dengan total ekuitasmengukur laba bersih sesudah pajak dengan modal sendiri dengan mengunakan metode yang ada pada rasio profitabilitas.

\section{METODE PENELITIAN}

Penelitian ini mengunakan metode penelitian deskriptif kualitatif yang menurut Sugiono (2012) yaitu untuk membuat gambaran atau fakta yang berhubungan dengan objek penelitian yang akan diteliti dengan memberikan suatu gambaran. Penelitian ini mengunakan data sekunder berupa data kuantitatif, yaitu data atau informasi yang berbentuk data-data yang dikumpulkan lalu dianalisa untuk dapat mengetahui modal kerja dan keuntungan di perusahaan Roti Tiga Berlin Kota Lubuklinggau Adapun data yang diperoleh berupa : 1) laporan neraca, 2) laporan laba rugi. Teknik pengumpulan data yang digunakan dalam penelitian ini adalah dokumentasi data laporan keuangan 
tahun 2013-2017 Perusahaan Roti Tiga Berlian Kota Lubuklinggau . Data yang diperlukan adalah sebagai berikut:

Agar memperoleh data dan informasi secara akurat diperlukan pembuktian dalam penelitian ini, dengan melakukan pengumpulan data dengan cara sebagai berikut: 1. Teknik Observasi. Teknik observasi menurut Sutrisno Hadi yang dikutib oleh Sugiyono (2016:145) mengemukakan bahwa, observasi merupakan suatu proses yang kompleks, suatu proses yang tersusun dari berbagai proses biologis dan psikhologis. Teknik pengumpulan data dengan observasi digunakan bila, penelitian berkenaan dengan perilaku manusia, proses kerja, gejala-gejala alam dan bila responden yang diamati tidak terlalu besar (Sugiyono, 2012).

2. Teknik Dokumentasi. Teknik pengumpulan data yang digunakan dalam penelitian ini salah satu nya adalah teknik dokumentasi data laporan keuangan tahun 20122016Perusahaan Roti Tiga Berlian Lubuklinggau.

b. Teknik Wawancara. Teknik pengumpulan data digunakan sebagai teknik pengumpulan data apabila peneliti ingin melakukan studi pendahuluan untuk menemukan permasalahan yang harus diteliti dan juga apabila ingin mengetahui halhal dari responden yang mendalam.

\section{Prosedur Analisis Data}

Dalam menganalisis data, penulis menggunakan metode deskriptif kualitatif, dimana data yang dikumpulkan, disusun, diinterprestasikan, dan dianalisis sehingga memberikan keterangan lengkap sebagai pemecahan masalah yang dihadapi.

Menurut Sugiyono (2012), Adapun prosedur analisis data dalam penelitian ini adalah dengan menggunakan teknik analisis sebelum di lapangan dan teknik analisis data selama di lapangan model spradley melalui pengumpulan data dokumentasi yaitu data berupa laporan keuangan yang terdiri dari neraca dan laba rugi Perusahaan Roti Tiga Berlian. Prosedur analisis data, antara lain.

1. Strategi Pengembangan Usaha. Analisis SWOT adalah suatu bentuk analisis di dalam manajemen perusahaan atau di dalam organisasi yang secara sistematis dapat membantu dalam usaha penyusunan suatu rencana yang matang untuk mencapai tujuan, baik itu tujuan jangka pendek maupun tujuan jangka panjang. Atau definisi analisis SWOT yang lainnya yaitu sebuah bentuk analisa situasi dan juga kondisi 
yang bersifat deskriptif (memberi suatu gambaran). Analisa ini menempatkan situasi dan juga kondisi sebagai sebagai faktor masukan, lalu kemudian dikelompokkan menurut kontribusinya masing-masing. Satu hal yang perlu diingat baik-baik oleh para pengguna analisa ini, bahwa analisa SWOT ini semata-mata sebagai suatu sebuah analisa yang ditujukan untuk menggambarkan situasi yang sedang dihadapi, dan bukan sebuah alat analisa ajaib yang mampu memberikan jalan keluar yang bagi permasalahan yang sedang dihadapi.

SWOT adalah singkatan dari:

$\mathrm{S}=$ Strength (kekuatan).

$\mathrm{W}=$ Weaknesses (kelemahan).

$\mathrm{O}=$ Opportunities (Peluang).

2. Modal Kerja. Perputaran Modal kerja (Working Capital Turn Over) merupaka rasio yang digunakan untuk mengukur keefektifan modal kerja (Aset Lancar) yang dimiliki perusahaan dalam menghasilkan penjualan (Herry, 2014)

Perputaran Modal Kerja $=\frac{\text { Penjualan }}{\text { Modal } \text { Kerja }}$

3. Keuntungan. Dalam menjalankan suatu usaha, keuntungan adalah raja. Keuntungan diartikan sebagai jumlah pendapatan dikurangi dengan jumlah pengeluaran, yakni jumlah uang yang "didapat" oleh sebuah usaha selama masa perhitungan tertentu, semakin banyak keuntungan yang didapatkan maka semakin baik, karena keuntungan dapat diinvestasikan kembali ke dalam usaha atau disimpan oleh pemilik usaha. Mampu menentukan keuntungan dalam usaha secara akurat merupakan bagian yang penting dalam sebuah usaha, agar dapat mempertimbangkan tingkat kesehatan finansial sebuah usaha

\section{HASIL PENELITIAN}

\section{Strategi Pengembangan Usaha}

Analisis SWOT adalah identifikasi berbagai factor secara otomais untuk merumuskan strategi perusahaan atau Usaha Kecil dan Menengah (UKM). Analisis ini didasarkan pada logina yang dapat memaksimalkan kekuatan (strengths) dan peluang (opportunities), namun secara bersamaan dapat meminimilkan kelemahan (weaknesses) dan ancaman (threats). Proses pengambilan keputusan strateguis selalu berkaitan dengan pengembangan misi, tujuan, strategi, dan kebijakan perusahaan. 
Dengan demikiajn perencana strategis harus menganalisis faktor-faktor strategis perusahaan (kekuatan, kelemahan, peluang, dan ancaman)perusahaan ini merupakan perusahaan yang memproduksi roti manis, roti tawar, donat dan roti kering dalam proses bisnis perusahaan kami melakukan penjualan melalui pedagang eceran dan melakukan distributor memproduksi roti tetapi pembeli atau distributor yang mengambil langsung ke pabrik, sehingga perusahaan ini melakukan aktivitas produksi yang akan memenhuhi permintaan konsumen/pelanggan. pabrik roti ini memproduksi roti manis, roti tawar, donat dan roti kering, prosedur kerja yang kami lakukan memproduksi terlebih dahulu untuk memenuhi stok pemasaran, perusahaan kami dalam 1 hari memproduksi 1.000 pack roti, selama 1 minggu memproduksi 4 hari, struktur organisasi perusahaan kami memilkinya karena dengan adanay struktur ini akan mampu membagi masing-masing tugas pokok dan fungsi karyawan, maka karyawan akan mengetahui tanggungjawab yang dimiliki karyawan tersebut untuk membantu proses produksi di Perusahaan Roti Tiga Berlian Kota Lubuklinggau, tenaga kerja yang bekerja sebanyak 15 karyawan, yang membantu proses produksi di Perusahaan Roti Tiga Berlian Kota Lubuklinggau,

Tujuan utama dari perusahaan untuk mendapatkan keuntungan dan juga memenuhi kebutuhan masyarakat, dan sasaran pemasaran yakni kota lubuklinggau, kabupaten musi rawas dan kabupaten musi rawas utara, Hasil wawancar dengan informan diketahui bahwa peluang dari perusahaan ini yaitu kami sudah lama mendirikan perusahaan roti sehingga sudah banyak orang yang mengetahui perusahaan kami dan kami mengetahui sasaran strategi pemasaran, ancaman setiap perusahaan memiliki pesaing misalnya banyak mucul toko roti dalam home industri maupun outlet, Roti tiga berlian berdiri sudah lama, Memiliki sasaran/wilayah pemasaran, Memahami kondisi pasar, Memiliki tenaga kerja yang kompeten dan Memiliki struktur organisasi yang jelas, dan menjadi ancaman Harga yang tidak stabil, Pesaing, Biaya transportasi/operasiona dan Belum memiliki toko atau otlet, masing-masing dari kekuatan, kelemahan, peluang dan ancaman di Perusahaan Roti Tiga Berlian Kota Lubuklinggau, dengan ancaman tersebut maka perusahaan roti akan menentukan sikap dan strategi agar perusahaan tetap dapat beroperasional walaupun pesaing yang semakin bertambah dna harga yang tidak stabil, letak posisi ataupun kedudukan Perusahaan Roti Tiga Berlian Kota Lubuklinggau jika dilihat dari peluang dan kekuatan yang dimiliki 
dan letak posisinya sudah strategis dengan aman dan banyak pelanggan tetap setia dengan perusahaan kami dalam membeli roti.

Strategi pengembangan usaha yang dilakukan dengan penilaian faktor internal (SW) dan eksternal (OT) dapat disimpulkan bahwa rekomendasi strategi pengembangan harus meneliti beratkan pada kelemahan (internal) untuk memaksimalkan peluang dari ekstenal, Rekomendasi strategi tersebut meliputi:

1. Menambah keberagaman varian roti. Penambahan berbagai jenis varian roti ini ditujukan untuk mengatasi fluktuatifnya harga produk yang disebabkan oleh perubahan bahan baku. Pemilihan jenis dan varian rasa sebaiknya didasarkan atas minat konsumen dan kestabilan harga bahan baku. Sehingga jika terdapat produk yang mengalami kenaikan harga, konsumen memiliki opsi untuk membeli jenis roti lainnya.

2. Membuka pabrik diwilayah yang strategis. Rekomendasi ini didasarkan untuk mengatasi biaya transportasi yang tinggi dan sekaligus untuk menjaga harga produk agar tidak fluktuatif. Pembukaan pabrik diwilayah lain juga bertujuan untuk memperluas pasar roti. Pembukaan pabrik diwilayah lain juga dapat dilakukan dengan sistem franchise, sehingga biaya permodalan inti perusahaan dapat ditekan dan sekaligus dapat menjadi bagian promosi pada wilayah lain.

3. Membangun otlet-otlet khusus untuk produk roti tiga berlian. Pembuatan otlet ini bertujuan untuk menjadi wadah pemasaran secara langsung ke konsumen dari pabrik dan sekaligus pengenalan akan keeklusifan produk. Pembukaan otlet ini juga dapat dilakukan melalui dukungan atau dengan sistem pemodalan bersama.

\section{Modal Kerja}

Berdasarkan analisa data maka untuk mengetahui pengelolaan modal kerja yang dimiliki oleh Perusahaan Roti Tiga Berlian diketahui bahwa selama 5 (lima) tahun dari tahun 2013 sampai tahun 2017, diketahui bahwa hasil wawancara dengan pimpinan dan bendahara maka dapat diketahui bahwa Untuk meningkatkan modal kerja dengan cara mengelolah modal kerja secara aktif di perusahaan, pertimbangkan pendanaan alternatif, membayar pemasok tepat waktu dan aktif mengelola saham/stok, selain itu dengan meningnya modal kerja akan membuat biaya terlihat sehingga akan lebih efektif mengelola proses pembayaran, untuk mengatasi modal kerja mengalami penutunan 
maka mampu mengelola persediaan modal dengan memaksimalkan kinerja dan menambah sasaran promosi, sleian itu penuruna kami melakukan dengan cara harus mengetahui modal kerja saat ini, kelola persediaan, mengelola faktur membuat rencan, peluang dari modal kerja akan meningkat demi menguntungkan perusahaan, meningkatkan hasil produksi dan mengoptimalkan manajemen keuntungan secara optimal dengan kemampuan perusahaan dengan baik

Perputaran Modal kerja (Working Capital Turn Over) merupaka rasio yang digunakan untuk mengukur keefektifan modal kerja (Aset Lancar) yang dimiliki perusahaan dalam menghasilkan penjualan (Herry, 2015 : 184) Adapun hasil perhitungan untuk mengetahui perputaran modal kerja di Perusahaan Roti Tiga Berlian Kota Lubuklinggau yaitu sebagai berikut: Hasil perhitungan tahun 2013 sebesar 108.5\%, dengan standar perhitungan menurut Peraturan Menteri Negara Koperasi dan UKM Republik Indonesai Nomor 6/Per/M. KUKM/2012 dengan $0<20$ dinyatakan sangat tidak sehat, $20<40$ tidak sehat, $40<60$ kurang sehat, $60<80$ cukup sehat, $80<100$ sehat, maka dengan hasil perhitungan sebesar $108.5 \%$ dapat dinyatakan dalam mengelola modal kera yang dimiliki maka Perusahaan Roti Tiga Berlian Kota Lubuklinggau dalam kondisi sehat.

Hasil perhitungan tahun 2014 sebesar 140.2\%, dengan standar perhitungan menurut Peraturan Menteri Negara Koperasi dan UKM Republik Indonesai Nomor 6/Per/M. KUKM/2012 dengan $0<20$ dinyatakan sangat tidak sehat, $20<40$ tidak sehat, $40<60$ kurang sehat, $60<80$ cukup sehat, $80<100$ sehat, maka dengan hasil perhitungan sebesar 140.2.\% dapat dinyatakan dalam mengelola modal kerja yang dimiliki maka Perusahaan Roti Tiga Berlian Kota Lubuklinggau dalam kondisi sehat.

Hasil perhitungan tahun 2015 sebesar 87.6\%, dengan standar perhitungan menurut Peraturan Menteri Negara Koperasi dan UKM Republik Indonesai Nomor 6/Per/M. KUKM/2012 dengan $0<20$ dinyatakan sangat tidak sehat, $20<40$ tidak sehat, $40<60$ kurang sehat, $60<80$ cukup sehat, $80<100$ sehat, maka dengan hasil perhitungan sebesar 87.6.\% dapat dinyatakan dalam mengelola modal kerja yang dimiliki maka Perusahaan Roti Tiga Berlian Kota Lubuklinggau dalam kondisi sehat.

Hasil perhitungan tahun 2016 sebesar 134.4\%, dengan standar perhitungan menurut Peraturan Menteri Negara Koperasi dan UKM Republik Indonesai Nomor 6/Per/M. KUKM/2012 dengan $0<20$ dinyatakan sangat tidak setuju, $20<40$ tidak setuju, 
$40<60$ kurang sehat, $60<80$ cukup sehat, $80<100$ sehat, maka dengan hasil oerhitungan sebesar $134.4 \%$ dapat dinyatakan dalam mengelola modal kerja yang dimiliki maka Perusahaan Roti Tiga Berlian Kota Lubuklinggau dalam kondisi sehat.

Hasil perhitungan tahun 2017 sebesar 157.7\%, dengan standar perhitungan menurut Peraturan Menteri Negara Koperasi dan UKM Republik Indonesai Nomor 6/Per/M. KUKM/2012 dengan $0<20$ dinyatakan sangat tidak sehat, $20<40$ tidak sehat, $40<60$ kurang sehat, $60<80$ cukup sehat, $80<100$ sehat, maka dengan hasil perhitungan sebesar $157.7 \%$ dapat dinyatakan dalam mengelola modal kerja yang dimiliki maka Perusahaan Roti Tiga Berlian Kota Lubuklinggau dalam kondisi sehat.

Berdasarkan analisa perhitungan selama 5 (lima) tahun bahwa dari tahun 2013 sampai tahun 2017, diketahui bahwa Perusahaan Roti Tiga Berlian Kota Lubuklinggau dalam mengelola modal kerja yag dimiliki dalam keadaan kondisi sehat, sehingga penggunaan modal kerja yang telah dianggap efektif untuk mampu memanfaatkan modal kerja di Perusahaan Roti Tiga Berlian Kota Lubuklinggau.

\section{Keuntungan}

Berdasarkan analisa data maka untuk mengetahui pengelolaan modal kerja yang dimiliki oleh Perusahaan Roti Tiga Berlian untuk menentukan laba (keuntungan) diketahui bahwa selama 5 (lima) tahun dari tahun 2013 sampai tahun 2017, diketahui bahwa hasil wawancara dari pimpinan dan bendahara diketahui bahwa sumber masalah pada keuntungan perusahaan menurunkan biaya harga produk, dan bertahap mulai faktor penghambat faktor masalah dan cara menyelesaikannya, kesempatan investasi semakin beasr, dengan memperluas jaringan usaha dan kinerja karyawan dengan menambah karyawan agar kinerja semakin baik, kesempatan investasi semakin besar besar dan antisipasi kerugian dan ancaman yang menyebabkan keuntungan dikarenakan persaingan produk yang tinggi, karena adanya pesaing dan kinerja pegawia yang berkurang.

Hasil Pengembalian atas Modal (Return on Equity) merupakan rasio yang menunjukkan seberapa besar kontribusi modal dalam menciptakan laba bersih.Cara mengukur rasio. Untuk menentukan kontribusi modal kerja untuk menciptakan laba bersih di Perusahaan Roti Tiga Berlian Kota Lubuklinggau. Adapun hasil perhitungan 
untuk mengetahui perhitungan Return On Equiyu (ROE) di Perusahaan Roti Tiga Berlian Kota Lubuklinggau yaitu sebagai berikut:

Nilai modal ditahun 2013 sebesar Rp.770.403.000,- maka keuntungan yang diterima sebesar Rp.228.900.000,- ditahun 2014 dengan nilai modal sebesar Rp.701.280.000,- maka dinilai keuntungan yang diterima sebesar Rp.396.060.000,ditahun 2015 dengan nilai modal sebsar Rp.981.680.000,- maka nilai keuntungan yang diterima sebsar Rp.93.830.000,- ditahun 2016 dengan modal sebesar Rp.752.340.000,dengan nilai keuntungan sebesar Rp.310.134.900,- dan ditahun 2017 dengan modal sebesar Rp.762.831.000,- dengan nilai keuntungan sebesar Rp.480.847.000,-.

Maka dengan demikian dapat diketahui bahwa kuntungan terbesar ditahun 2017 dan terendah ditahun 2015, nilai tersebut menunjukkan bahwa nilai modal yang diperoleh oleh Perusahaan Roti Tiga Berlian Kota Lubuklinggau maka nilai modal yang besar tidak mempengaruhi keuntungan yang diterima oleh Perusahaan Roti Tiga Berlian Kota Lubuklinggau untuk modal kerja yang dimiliki untuk memperoleh keuntungan maka dalam keadan sehat, sehingga Perusahaan Roti Tiga Berlian Kota Lubuklinggau diaggap selama 5 (lima) tahun diketahui bahwa mampu menggunaakn modal kerja yang dimiliki untuk mendapatkan laba di Perusahaan Roti Tiga Berlian Kota Lubuklinggau

\section{PEMBAHASAN}

Perusahaan Roti Tiga Berlian Kota Lubuklinggau diketahui bahwa modal kerja yang digunakan untuk operasional kegiatan usaha dengan menggunakana analisa swot maka dapat mengetahui strategi yang tepat agar Perusahaan Roti Tiga Berlian Kota Lubuklinggau dapat mengetahui kekuatan yang dimiliki Perusahaan Roti Tiga Berlian Kota Lubuklinggau untuk mampu bertahan dan bersaing diantara produksi-produksi ukm lainnya di Kota Lubuklinggau dan sekitarnya, Perusahaan Roti Tiga Berlian Kota Lubuklinggau akan mempertimbangkan kelemahan yang dimiliki oleh Perusahaan Roti Tiga Berlian Kota Lubuklinggau agar dapat memperkecil resiko terjadi kerugian atas produksi yang dilakukan oleh Perusahaan Roti Tiga Berlian Kota Lubuklinggau dengan demikian maka dapat diketahui bahwa ancaman yang akan diterima oleh Perusahaan Roti Tiga Berlian Kota Lubuklinggau dikarenakan pabrik roti, ukm roti, ataupun toko roti yang telah memberikan kenyamanan telah cukup banyak berkembang di Kota Lubuklinggau menjadi dasar pertimbangan dalam penentuan pengelolaan dan 
penggunaan modal kerja yang dimiliki oleh Perusahaan Roti Tiga Berlian Kota Lubuklinggau, selain itu peluang yang dimiliki menjadi bahan pertimbangan paling tepat untuk memasarkan produk yang dimiliki karena sebagai perusahana yang memproduksi maka hasil penjualan yang menjadi sumber pendaptatan utama Perusahaan Roti Tiga Berlian Kota Lubuklinggau

Perusahaan Roti Tiga Berlian Kota Lubuklinggau dapat mengembangkan usaha yang dimiliki dengan mempertimbangkan peluang yang dimiliki dengan menambah strategi pemasaran agar dapat mengembangkan usaha yang ada, selain itu mampu menciptakan inovasi yang baru agar mampu mencapai kepuasan pelanggan atau konsumen dengan demikian dapat meningkatkan profitabilitas dengan pengelolaan modal kerja yang baik maka dapat meningkatkan profitabilitas Perusahaan Roti Tiga Berlian Kota Lubuklinggau

Soelaiman Hardi. 2016. Analisis Perhitungan dan Strategi Pengembangan Usaha Lobster (Panulirus spp).Pada CV Sea Queen Kota Kendari.Penelitian ini bertujuan untuk mengetahui struktur biaya, tingkat pendapatan dan strategi pengembangan pada usaha perdagangan lobster laut di CV Sea Queen Kota Kendari.Lokasi peneltian ditentukan seara purposive, pengumpulan data dilakukan dengan metode wawancara, observasi dan dokumentasi, yang bersumber dari pemilik usaha 1 (orang) dan 6 (karyawan). Hasil penelitian menunjukkan bahwa struktur biaya usaha terdari dari investasi usaha sebesar Rp. 1.357.721.000,- biaya tetap sebesar Rp.192.406.548/tahun dan biaya variabel sebesar Rp.1.637.932.600/tahun, sehingga total biaya sebesar Rp.1.830.399.148/tahun. Pendapatan kotor (penerimaan) sebesar Rp.2.100.000.000/tahun dan pendapatan bersih (keuntungan) Rp.269.660.852/tahun. Dalam pengembangan usaha perusahaan terdapat 8 strategi yaitu memanfaatkan teknologi yang semakin pesat, menambah modal usaha, meningkatkan kapasitas produk, meningkatkan promosi, perekrutan tenaga kerja, meningkatkan volume produksi lobster, melakukan strategi stok bahan baku, dan meningkatkan seluruh sumber daya yang dimiliki usaha lobster.

Evan Filbert. 2018. Kajian Strategi Pengembangan Usaha pada Industri Konveksi "Scot Shop" di Cibubur.Industri konveksi sebagai salah satu industri yang dibutuhkan masyarakat dalam pemenuhan kebutuhan sandang memiliki peluang dan persaingan pasar yang relatif besar, begitu pula halnya pada industri konveksi Scout 
Shop di Cibubur. Tujuan kajian ini adalah untuk mengaanlisis dan mengevaluasi faktorfaktor internal dan eksternal yang mempengaruhi kelangsungan usaha serta menyusun strategi yang tepat dalam upaya pengembangan konveksi. Dalam mengidentifikasi faktor SWOT pada kondisi obyek, menentukan skla prioritas tiap strategi dengan analytical hierarchy process.Serta merancang kebijakan strategi pengembangan usaha konveksi Scout Shop.Cibubur dengan berbagai strategi analisa SWOT. Hasil peneltiian menunjukkan bahwa kondisi UKM Scout Shop saat ini lebih kearah posis Strenghts dan Opportunities (SO) sehingga dalam pengembangan usaha konveksi Scout Shop, perusahaan perlu menggunakan kekuaran untuk memanfaatkan peluang, terdapat beberapa beberapa strategi yang dilakukan diantaranya: diverifikasi, peningkatan mutu, melakukan produksi dalam kapasista yang lebih besar, serta peningkatan pemasaran.

\section{SIMPULAN}

Setelah melakukan analisa dan perhitungan dengan tujuan untuk mengetahui analisis strategi pengembangan usaha guna meningkatkan modal kerja dan keuntungan di Perusahaan Roti Tiga Berlian Kota Lubuklinggau, disimpulkan bahwa:

1. Peningkatkan modal kerja dengan cara mengelolah modal kerja secara aktif di perusahaan, pertimbangkan pendanaan alternatif, membayar pemasok tepat waktu dan aktif mengelola saham/stok untuk meningkatkan hasil produksi dan mengoptimalkan manajemen keuntungan secara optimal dengan kemampuan perusahaan dengan baik, dengan memperluas jaringan usaha dan kinerja karyawan dengan menambah karyawan agar kinerja semakin baik, kesempatan investasi semakin besar besar dan antisipasi kerugian dan ancaman yang menyebabkan keuntungan dikarenakan persaingan produk yang tinggi, karena adanya pesaing dan kinerja pegawia yang berkurang.

2. Berdasarkan analisa perhitungan selama 5 (lima) tahun bahwa dari tahun 2013 sampai tahun 2017, diketahui bahwa Perusahaan Roti Tiga Berlian Kota Lubuklinggau dalam mengelola modal kerja yag dimiliki dalam keadaan kondisi sehat, sehingga penggunaan modal kerja yang telah dianggap efektif untuk mampu memanfaatkan modal kerja di Perusahaan Roti Tiga Berlian Kota Lubuklinggau.

3. Berdasarkan hasil analisa dan perhitungan maka dapat diketahui bahwa kondisi Perusahaan Roti Tiga Berlian Kota Lubuklinggau dalam mengelola modal kerja 
yang dimiliki untuk memperoleh keuntungan maka dalam keadan sehat, sehingga Perusahaan Roti Tiga Berlian Kota Lubuklinggau diaggap selama 5 (lima) tahun diketahui bahwa mampu menggunaakn modal kerja yang dimiliki untuk mendapatkan laba di Perusahaan Roti Tiga Berlian Kota Lubuklinggau

\section{DAFTAR PUSTAKA}

Fahmi, Irham. (2014). Analisis Kinerja Keuangan. Cetakan ke III. Bandung : Alfabeta. Hery. (2014).Controllership. Cetakan ke II. Jakarta: PT Grasindo.

Hilbert, Evan, (2018). Kajian Strategi Pengembangan Usaha Pada Industri konveksi "Scouth Shop" di Cibubur. Jurnal

Jumingan. (2016). Analisis Laporan Keuangan. Jakarta : PT. Raja Grafindo Persada. Kasmir. (2015). Analisis Laporan Keuangan. Cetakan ke 8. Jakarta: Rajawali pers. Munawir. (2016). Analisis Laporan Keuangan. Cetakan ke 17. Yogyakarta: Liberty.

Soelaiman, Hardi. (2016). Analisis keuntungan dan strategi pengembangan usaha lobster (panulirus SPP) pada CV. Sea Queen Kota Kendari

Sugiyono. (2012). Metode peneltian bisnis. Bandung: Alfabeta. 